\title{
A UTILIZAÇÃO DE ADORNOS CORPORAIS NA PRÉ- HISTÓRIA DA ÁREA ARQUEOLÓGICA DO SERIDÓ - RN
}

\section{THE USE OF PERSONAL ORNAMENTS IN PREHISTORY OF THE ARCHAEOLOGICAL AREA OF SERIDÓ - RN}

\author{
Daniela Cisneiros ${ }^{1}$ \\ danielacisneiros@yahoo.com.br \\ Nathalia Nogueira ${ }^{2}$ \\ Nathalia.c.nogueira@gmail.com \\ Camila Santos ${ }^{2}$ \\ amilaferreirasantos12@gmail.com
}

\begin{abstract}
RESUMO
Os adornos corporais estão entre as primeiras manifestações simbólicas produzidas pelo Homo sapiens e evidenciadas em dados arqueológicos. São fontes portadoras de informações sobre tecnologia e identidade. A região do Seridó apresenta em seu acervo arqueológico elementos materiais e gráficos que atestam o uso desses adornos na préhistória. O presente artigo tem por objetivo apresentar as tipologias, usos e funções dos adornos nos contextos funerários e rupestres do Seridó Potiguar. Os dados de 11 sítios analisados permitiram inferir que os grupos que habitaram a região em períodos préhistóricos utilizavam-se de adornos de diversas tipologias (adornos de cabeça, colares e pingentes); confeccionados com diferentes matérias-primas e utilizados em distintos contextos (rituais funerários, caça, sexo e violência).
\end{abstract}

Palavras-chave: Adornos corporais, Pré-história do Seridó, Pintura Rupestre.

${ }^{1}$ Departamento de Arqueologia da UFPE.

${ }^{2}$ Discente do Programa de Pós Graduação em Arqueologia da UFPE. 


\begin{abstract}
The personal ornaments are among the first symbolic manifestations produced by Homo sapiens sapiens and manifested in archaeological data. They are sources of information about technology and identity. The Seridó region has material and graphic elements in its archaeological collection that attest to the use of ornaments in prehistory. This paper aims to present the types, uses, and functions of ornaments in the funerary and rock art of Seridó Potiguar. The data from 11 analyzed sites allowed us to infer that the groups that inhabited the region in prehistoric periods used ornaments of different types (head ornaments, necklaces, and pendants) made with different raw materials and used in different contexts (funerary rituals, hunting, sex, and violence).
\end{abstract}

Keywords: Personal ornaments, Seridó Prehistory, Rock Art.

\title{
CONTEXTO DA PESQUISA
}

Estudos sobre os adornos corporais pré-históricos e seus aspectos técnicos, funcionais e formais, têm adquirido uma crescente importância na Arqueologia. $\mathrm{O}$ interesse pela origem da consciência simbólica do gênero Homo é um dos assuntos mais debatidos na Arqueologia Evolutiva e Cognitiva. Dentre os modelos propostos para estudar o aparato simbólico da espécie sapiens, estão sobretudo as análises das práticas funerárias; da arte rupestre e a arte móvel e dos adornos corporais.

Embora tenham adquirido ênfases mais funcionais e simbólicas no esteio da Arqueologia funerária, o interesse da Arqueologia pela temática vem desde meados do século XIX. Entre as primeiras documentações sobre adornos pré-históricos, pode-se destacar: L'Homme Primitif (1870) de L. Figuier. Em um dos principais trabalhos da época sobre essa temática, o autor faz referência ao papel simbólico e social dos adornos, destacando as matérias-primas e seus usos em contextos etnográficos. Nessa mesma época, outros trabalhos se configuram como referência 
sobre a temática: Prehistoric Times (1865) de J. Lubbock e An Introduction to the Study of Prehistoric Art (1915) de E. Parkyn, estão entre as primeiras obras que discutem e apresentam tipologias e matérias-primas de adornos.

Os estudos dos adornos nos registros rupestres surgem a partir das análises cenográficas e de significantes gráficos em contexto de temáticas reconhecíveis, como antropomorfos isolados ou representados em cenas de guerra, sexo, dança e caça, onde para além dos elementos primários de reconhecimento, pode-se observar em alguns contextos elementos secundários como cocares, argolas, e adornos de pernas e braços. As primeiras apresentações sobre adornos pessoais na literatura arqueológica datam do início do século XX. Em El Hombre Fósil (1925) de H. Obermaier, o autor, faz uma análise das representações rupestres dos adornos da Arte Levantina integrando-os em uma análise de caracterização gráfica.

A partir de meados do século XX, o cenário arqueológico começa a apresentar fortes mudanças teóricas e metodológicas. Dentro desse novo cenário, o estudo dos adornos começa a ganhar destaque para além da descrição morfológica, com análises contextuais, arqueométricas e experimentais. Através das análises sistemáticas dos adornos, dentro dos contextos arqueológicos e ambientais, o pesquisador pode obter dados relevantes sobre as técnicas, as funções e os significados desses objetos e suas interações com os aspectos da vida social e cultural de grupos pré-históricos. 
Este artigo tem como objetivo apresentar e descrever as tipologias, usos e funções dos adornos nos contextos funerários e rupestres na Área Arqueológica do Seridó Potiguar. Considerando sua importância na identificação da exteriorização cultural de determinados grupos, dada a identidade pessoal e coletiva que esses objetos carregam.

\section{UTILIZAÇÃO E FUNÇÃO DOS ADORNOS}

Os adornos pessoais são elementos empregados para dar destaque ao corpo e podem ser estudados e interpretados como um sistema de comunicação. A capacidade cognitiva da espécie sapiens permitiu estabelecer uma consciência própria e diferenciada que se materializa em alguns signos, tais como: adornos, arte rupestre e enxoval funerário, que permitem a elaboração de uma identidade individual e coletiva.

$\mathrm{Na}$ Arqueologia os principais critérios empregados para incluir um objeto dentro da categoria de adorno são: a dimensão reduzida e a morfologia; o contexto arqueológico no qual foi evidenciado; as analogias com materiais etnográficos; e a presença de elementos de suspensão e amarração. É importante considerar que a etnografia aponta para diferentes tipologias e condutas simbólicas na utilização dos adornos. Considera-se adornos os elementos que se agregam permanentemente ao corpo, como tatuagens e escarificações voluntárias; os elementos que se agregam ao corpo, mas não modificam sua estrutura e podem ser facilmente removíveis, como colares, pingentes, braçadeiras, tornozeleiras, pulseiras; e os elementos que 
transformam o corpo, mas podem ser removíveis como brincos, alargadores auriculares e labiais.

Mesmo parecidos morfologicamente, os adornos podem apresentar significados diferentes levando em consideração à distinção cultural e temporal dos grupos. Podem ter condutas simbólicas diferenciadas, com sua utilização ordinária ou em momentos específicos como danças, rituais de passagem, guerras e matrimônios. E podem também indicar distinções sexuais, etárias e sociais (Figura 1).

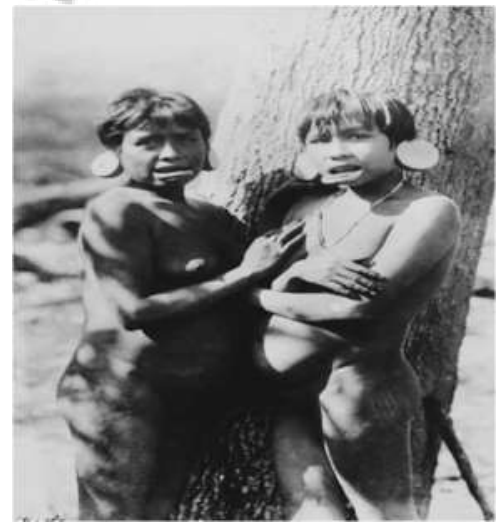

A)

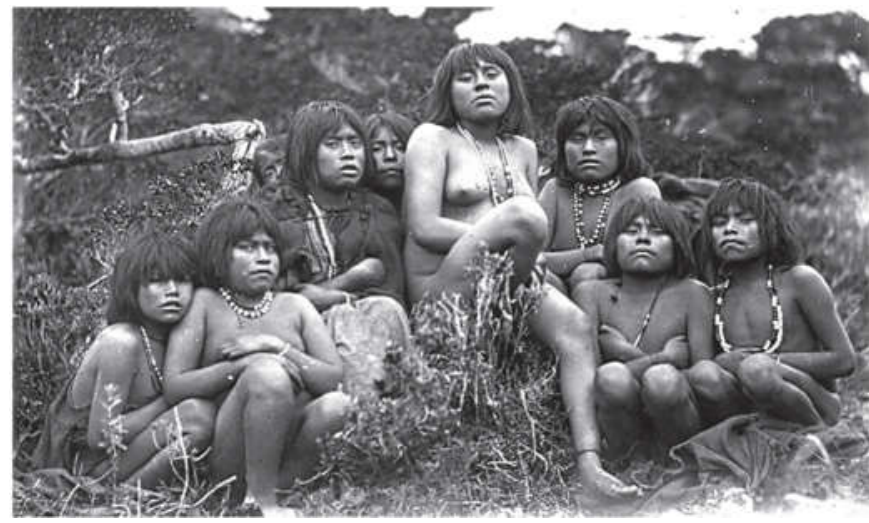

B)

Figura 1: A) Índios Botocudos com adornos labiais. Fonte: Ehrenreich (2014). B) Jovens yámana/yagán usando colares de contas. Fonte: Butto; Fiore (2017).

Em relação à matéria-prima, nota-se um arsenal diverso que envolve materiais orgânicos (fauna e flora), tais como ossos, conchas, penas, sementes; e materiais inorgânicos, como minerais e rochas. 
Pode-se considerar o corpo como atributo de um sistema de comunicação visual, com estruturas simbólicas para os diversos momentos sociais e religiosos, contendo relações com os outros meios comunicacionais, tanto os verbais quanto os não verbais (Seeger, Matta e Castro, 1979).

Dentro dos estudos sobre a Pré-história, o adorno, como remanescente cultural exprime características que auxiliam no estabelecimento de recorrência e padrões, estes por sua vez, levam a identificação de ligações e inter-relações entre diferentes grupos. Como já mencionado, os atributos culturais têm importância e significância dentro do universo grupal para a representação do indivíduo, ressaltando que suas características estão intimamente ligadas à cultura de cada grupo, contendo na imagem final, uma demonstração de padrões associáveis à diferentes membros da sociedade e sua identificação perante eles.

Leroi-Gourhan (1965), aponta que esse tipo de atributo se apresenta como decoração que reporta à múltiplos aspectos da organização social, perante a sua necessidade de caracterização para a constituição da identidade pessoal; sua inserção dentro do grupo; e posição social e sexual. Assim, viver com o traje relativo ao seu grupo assegura simultaneamente a sensação de existir enquanto elemento individual de um grupo, onde se desempenha um papel a nível pessoal, e uma sensação de oposição relativa aos outros grupos. Os atributos adornais têm, sobretudo, um valor étnico, pois a presença a um dado grupo começa por ser sancionada em função da decoração. Assim, pode-se definir que o corpo é um 
suporte comunicacional, onde são atrelados atributos que carregam um valor étnico e simbólico pertencente a grupos distintos, diferenciando-os entre si, considerando que estão carregados de sinais que permitem tais distinções. Esses símbolos, de acordo com Velthem (2007), sintetizam propriedades que derivam de aspectos espaciais, temporais e sociais, cujo significado é completado através da integração de seus componentes estruturais, conceituais e relacionais.

Ou seja, o objeto, neste caso o adorno, apresenta em sua estrutura morfológica características do ambiente natural, cultural e social de seu tempo, onde os significados estão atrelados aos elementos de sua composição, aos conceitos culturais de cada grupo e às relações atribuídas ao conjunto. Contemplando, assim, características do meio cujos aspectos podem permanecer interligados por gerações. De um modo geral, ornar-se constitui dado cultural universal e elemento significativo para a construção social do corpo humano (Dorta e Cury, 2000).

\section{OS ADORNOS NA PRÉ-HISTÓRIA}

Os adornos estão entre as primeiras manifestações simbólicas produzidas pelo Homo sapiens sapiens e evidenciadas em dados arqueológicos. São fontes portadoras de informações sobre tecnologia e identidade, Mayor e Benito (2006) ressaltam o uso dos adornos em contextos de subsistência e vinculados à contextos funerários durante o Paleolítico Superior na Europa. Foram verificados colares e braceletes de conchas, muitos adornos de cabeça, dentes e vértebras de pequenos mamíferos. Binant (1991), por sua vez, observou que, no Paleolítico Superior, os 
adornos identificados em contexto funerário eram utilizados com diversas morfologias e distintas matérias-primas. Enterramentos de indivíduos adultos e jovens apresentavam uma maior evidência de adornos em conchas, ossos e vertebras de peixes, enquanto os enterramentos infantis estavam associados a adornos confeccionados a partir de dentes de animais e/ou conchas.

No Brasil são verificados, com recorrência, sítios pré-históricos com adornos corporais identificados em contextos funerários, que possibilitam interpretações de ordem contextual, indicando a que usos se destinavam e com quais indivíduos estavam relacionados. Os primeiros adornos corporais identificados no Brasil foram alguns ossos de megafauna (Glossotherium lettsomi), transformados em pingentes em períodos Pleistocênicos, datados em 27000 anos BP, no Abrigo Santa Elina, no Mato Grosso. Porém, Vialou e Vialou (2019), situam a maioria dos adornos identificados nesse sítio, como pertencentes a períodos mais recentes de ocupação, cerca de 2000 a 4000 anos BP, tais como colares, pulseiras, braçadeiras, estojos penianos, esses adornos foram confeccionados em ossos, conchas, vegetais e rochas. Também foram verificados tembetás, datados do Holoceno inicial.

Para o Nordeste do Brasil, Santos (2020), aponta que as tipologias mais frequentes de adornos evidenciados em contextos funerários são as contas e pingentes, que formam adornos de pescoço e, por vezes, de pulso. Segundo a autora, percebe-se que as contas e os pingente tendem a ter maior variabilidade de matérias-primas em sítios com cronologias mais recentes, provavelmente em razão do tempo de vida 
dos materiais utilizados, os quais permitem aos sítios, com datações de até 2000 anos BP, apresentem adornos fabricados em madeira, por exemplo.

A partir dos dados cronológicos publicados para o Nordeste do Brasil, foi possível definir, de modo preliminar, que sítios com datações recuadas, cerca de 8000 e 7000 anos BP, apresentam, com maior frequência, adornos confeccionados em material ósseo, dentes e conchas. Por volta dos 6000 anos BP, observa-se maior variedade de matérias-primas em sua produção, com a inclusão de diversas espécies de sementes e o uso de madeira como ornamentação. Outras matérias-primas e muito provavelmente, as penas também devem ter sido utilizadas por grupos préhistóricos, porém não são mais observadas ou aparecem em menor escala no registro arqueológico (Santos, 2020).

\section{ÁREA ARQUEOLÓGICA DO SERIDÓ: CONTEXTO E CRONOLOGIA}

A Área Arqueológica ${ }^{3}$ do Seridó, localizada entre os estados do Rio Grande do Norte e da Paraíba, configura-se entre as áreas de maior concentração de sítios arqueológicos da região Nordeste do Brasil. A investigação sistemática nessa área teve início após a década de 1980, sob a coordenação da arqueóloga Gabriela Martin. Segundo Martin (2008), as primeiras prospecções na área foram para constatar a autenticidade de desenhos rupestres copiados pelo autodidata José de Azevedo Dantas (1994). Em decorrência dessas prospecções e do número de sítios

\footnotetext{
${ }^{3}$ Uma Área Arqueológica pode ser estabelecida a partir da compreensão das divisões geográficas que compartilham das mesmas condições ecológicas e nas quais possuem um número expressivo de sítios arqueológicos (Martin, 2008).
} 
identificados, a região foi assinalada como área arqueológica. Em um primeiro momento, as pesquisas se concentraram nas análises dos abrigos com registros rupestres, considerando os aportes temáticos, cenográficos e técnicos dos grafismos, assim como o contexto arqueológico oriundo das escavações e identificação de vestígios arqueológicos evidenciados nesses abrigos.

Desde o início do século XXI, a pesquisa na área foi ampliada para sítios a céu aberto, onde se iniciaram estudos sobre a distribuição espacial e o uso dos recursos naturais por grupos pré-históricos. Com o avanço das pesquisas e aumento do número de sítios e dados arqueológicos para a área, foi possível começar a segregar diferentes categorias de vestígios arqueológicos e relacioná-los com o uso do espaço que vai desde a utilização dos abrigos em planos altimétricos superiores às zonas mais baixas e a sítios próximos ao leito dos rios (Borges, 2010; Nogueira, 2017).

A região do Seridó se caracteriza por dois contextos geomorfológicos diferentes, o Planalto da Borborema (com altitude entre $400 \mathrm{~m}$ e $700 \mathrm{~m}$ ) e as seções mais reduzidas da Depressão Sertaneja (250 m e 350 m). Essas diferenças altimétricas geram paisagens distintas entre partes mais elevadas das serras e partes mais rebaixadas, gerando uma vista plana. Apresenta atualmente um contexto semiárido com clima quente e seco, com uma precipitação média anual de 447,8 mm (Cisneiros, Nogueira \& Tavares, 2020). 
Ainda não se tem dados suficientes para estabelecer uma cronologia contínua no que se refere à ocupação humana pré-histórica na Área Arqueológica do Seridó. Entretanto, a partir das datações absolutas e análises de vestígios provenientes de escavações arqueológicas foi possível constatar uma ocupação a partir de $9400 \pm$ 90 anos B.P para área. Dos sítios pré-históricos identificados na região do Seridó Potiguar, a maior concentração localiza-se no município de Carnaúba dos Dantas, provavelmente em razão da intensidade de prospecções realizadas no local até o momento. A área integra um grande número de sítios, contendo pinturas e gravuras rupestres, sítios cemitérios e habitacionais.

\section{MATERIAIS E MÉTODOS}

Para a presente pesquisa foi realizado o levantamento das evidências arqueológicas de adornos nos enterramentos pré-históricos e nos grafismos rupestres dos sítios localizados na Área Arqueológica do Seridó Potiguar. Foram selecionados onze (11) sítios arqueológicos. Dois deles apresentaram adornos associados à esqueletos: Sítio Mirador, localizado no município de Parelhas e sítio Pedra do Alexandre, localizado no Município de Carnaúba dos Dantas; e nove sítios com cenas rupestres que apresentavam antropomorfos utilizando adornos de cabeça, são eles: Casa Santa, Furna da Desilusão, Furna do Borrachinha, Furna do Mateus, Serrote das Areias, Sítio do Helder, Xique-Xique XI, Xique-Xique II e Xique-Xique IV, todos localizados no município de Carnaúba dos Dantas (RN) (Figura 3). 

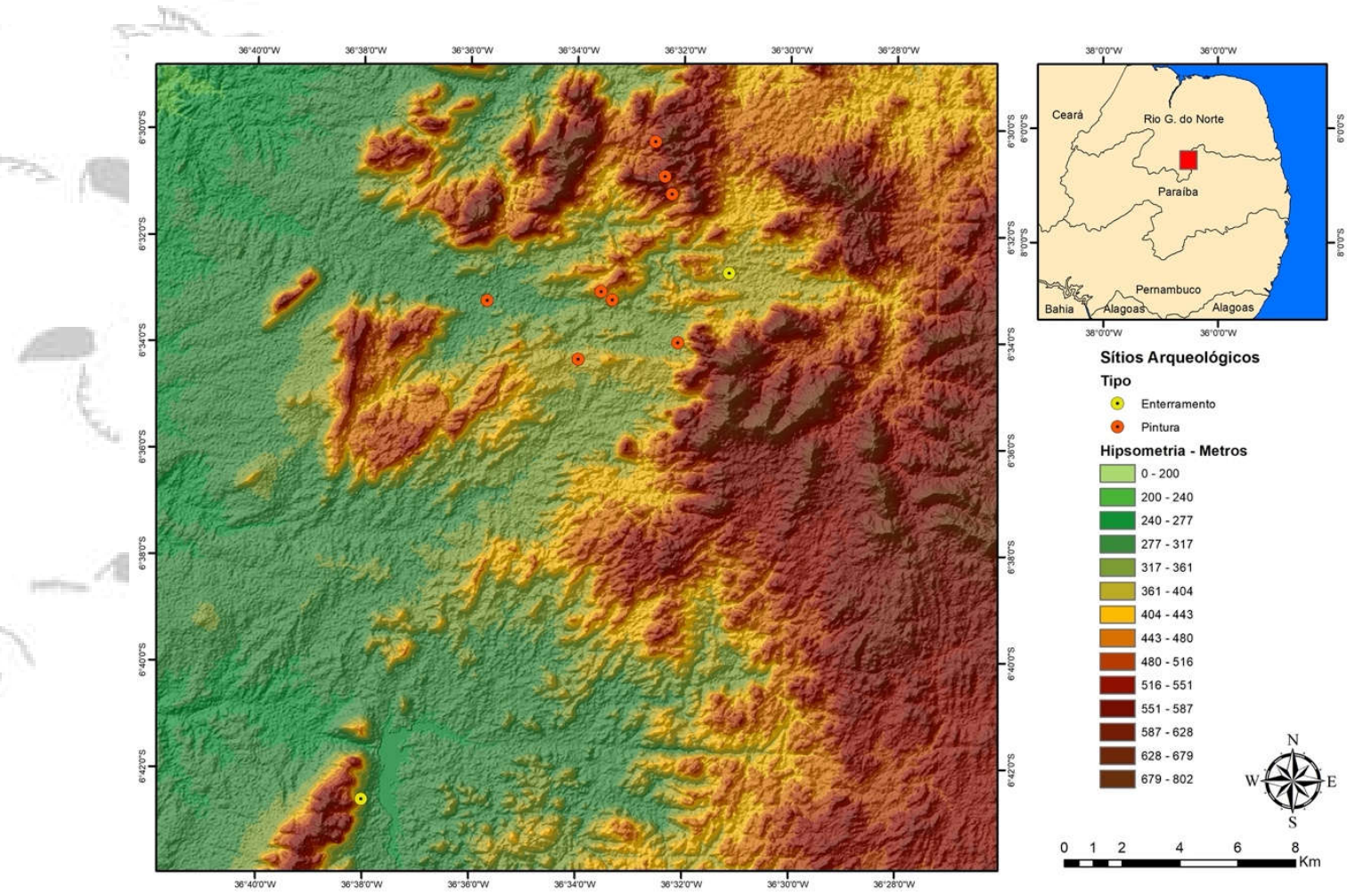

Figura 3: Mapa com a distribuição dos sítios.

Com o objetivo de definir os tipos e os usos desses adornos, nos enterramentos e nos registros rupestres, foram elencadas variáveis tecnológicas e tipológicas. Para os adornos presentes nos enterramentos foram estabelecidos os seguintes descritores: contexto funerário, matéria-prima, morfologia e dimensão. No contexto funerário, foi analisado o tipo de enterramento (primário e secundário), dados biológicos (sexo e idade) do esqueleto e cronologia. Quanto à matéria-prima, é válido salientar a importância da análise do tipo de base utilizada na produção dos 
adornos; essas são indicativos tanto de contextos ambientais quanto culturais. Como mencionado, em contexto pré-histórico, os tipos de matérias-primas mais observadas são ossos, dentes, conchas, seguidos pelos minerais e rochas. Nos contextos funerários mais preservados, também podem ser verificados adornos confeccionados com sementes e madeira. A variável morfológica será prioritária na identificação dos tipos de adornos, a qual se encontra em associação direta ao modo de uso.

Os tipos de adornos frequentemente verificados em contexto arqueológico são as contas e os pingentes. As contas geralmente são definidas a partir de sua morfologia e de seu sistema de fixação, que frequentemente se encontra no terço central da peça. Já os pingentes ou pendentes podem ser peças de formato mais alongado, ou seja, o comprimento maior que a largura, com sistema de suspensão situado também no terço externo da peça, com uma perfuração única ou dupla. Em contexto arqueológico também foram identificados adereços de cabelo, braceletes e tembetás. A mensuração dos adornos foi realizada em função do comprimento, largura e espessura; as dimensões podem dar ideia da utilização do adereço.

Para os adornos identificados nos registros rupestres foram consideradas as seguintes variáveis: cenografia, tipo de cena, morfologia e cor. Para a identificação das cenas, é necessário o reconhecimento de significantes gráficos correlatos ao nosso universo simbólico. A exemplo do reconhecimento das cenas de caça, faz-se necessário a identificação de elementos antropomórficos, zoomórficos, objetos ou 
ações que indiquem o aprisionamento do animal, caso contrário, a cena não poderá ser definida como caça. Para a morfologia dos adornos foram considerados os tipos gráficos semelhantes e diferentes presentes como elementos secundários na composição do antropomorfo. Essa variável foi trabalhada como a principal para a definição de tipos e variantes. Na categoria cor, considerou-se os matizes utilizados de monocromia ou bicromia e a parte da estrutura da figura a que correspondia o matiz.

Para ambas as análises foram levantados dados geomorfológicos e arqueológicos dos sítios. Essas categorias, como localização, posicionamento topográfico, cronologia, tipo de sítio e suporte permitem a reconstituição do contexto arqueológico desses adornos.

\section{ADORNOS EM CONTEXTOS FUNERÁRIOS NA ÁREA ARQUEOLÓGICA DO SERIDÓ}

Dentre os sítios com presença de práticas funerárias na Área Arqueológica do Seridó, apenas dois sítios Mirador de Parelhas e Pedra do Alexandre apresentaram presença de adornos no contexto funerário. O Sítio arqueológico Pedra do Alexandre, escavado durante várias campanhas desde a década de 1990, sob a coordenação de Gabriela Martin, está localizado no município de Carnaúba dos Dantas, no Rio Grande do Norte. O sítio é um abrigo sob rocha arenítica, com abertura para o sudeste, situado no topo de uma pequena elevação, com altitude de 
$380 \mathrm{~m}$. O Pedra do Alexandre apresenta um conjunto de pinturas rupestres disposta em uma extensão de $5,5 \mathrm{~m}$.

Os resultados das escavações arqueológicas, até então, apontam para a existência de três estratos: o primeiro apresenta vestígios de ocupação, com abundância de carvões e fogueiras estruturadas, restos de lascamento e instrumentos líticos em quartzo e sílex; o segundo estrato representa a ocupação do sítio como cemitério, e o terceiro estrato demonstra uma terra clara e compactada até o fundo do abrigo (Castro, 2009). Foram evidenciados, na Pedra do Alexandre 31 enterramentos, entre primários e secundários, obtendo-se uma sequência cronológica de 9400 a 2000 anos BP.

Os indivíduos foram depositados em covas, utilizando-se fogueiras rituais, que em alguns casos não chegavam a queimar completamente os ossos. Entre os acompanhamentos funerários observam-se os apitos e entre os adornos corporais observam-se os pingentes, contas de colar de ossos, conchas e amazonita (Martin, 2008) (Quadro 1). 


\begin{tabular}{|c|c|c|c|}
\hline $\begin{array}{c}\text { Número do } \\
\text { enterramento }\end{array}$ & $\begin{array}{c}\text { Tratamento } \\
\text { do corpo -uso } \\
\text { de ocre }\end{array}$ & Adornos & $\begin{array}{c}\text { Acompanhamentos } \\
\text { funerários e outros } \\
\text { materiais } \\
\text { associados }\end{array}$ \\
\cline { 1 - 1 } & Presente & Contas de colar & - \\
\hline 2 & Ausente & Colar com pingente de ossos de cervídeo & $\begin{array}{c}\text { Apito de osso, } \\
\text { rochas sobre o } \\
\text { tórax }\end{array}$ \\
\hline 44 & Ausente & Contas de colar & - \\
\hline 6 & Ausente & Contas de malacológico & - \\
\hline 8 & Presente & Colar de sementes e ossos e colar de ossos & $\begin{array}{c}\text { Conjunto de } \\
\text { quartzo }\end{array}$ \\
\hline 11 & Presente & Contas de colar & - \\
\hline 15 & Ausente & Contas de colar & - \\
\hline
\end{tabular}

Quadro 1: Dados sobre o tratamento destinado ao corpo, presença de adornos e outros materiais associados dos enterramentos escavados no Sítio Pedra do Alexandre Fonte: Adaptado de Cisneiros (2003); Martin (2008) e Santos (2020)

O Sítio Boqueirão de Parelhas ou Mirador de Parelhas foi escavado também sob coordenação de Gabriela Martin, na década de 1980. Está localizado no município de Parelhas, a 1 km de distância do Vale do Rio Seridó. O sítio é um abrigo sob rocha granítica, com $3 \times 4 \mathrm{~m}$ de superfície e altitude de $480 \mathrm{~m}$. A primeira sondagem nesse sítio foi realizada a oeste do paredão, a camada arqueológica tinha $60 \mathrm{~cm}$ de espessura, e ali, foram identificados enterramentos secundários. Os ossos evidenciados correspondem a um enterramento infantil duplo, parcialmente incinerado, com contas de colar de ossos e conchas marinhas e acompanhamento funerário com algumas lascas de quartzo e sílex. Além disso, foram evidenciados restos malacológicos, a partir dos quais Martin (2008) cogita a possibilidade de também fazerem parte do enxoval funerário. Para esse sítio, foi obtida uma datação 
de 9410 anos BP, contemporânea à ocupação do Sítio Pedra do Alexandre, porém as escavações não deram seguimento devido à depredação do abrigo.

Nos sítios Pedra do Alexandre e Mirador de Parelhas foram identificados duzentos e trinta e dois $(232)^{4}$ adornos corporais fabricados a partir de dentes, ossos, conchas, minerais e rochas. O sítio Pedra do Alexandre apresenta preponderantemente a maior quantidade de adornos, aos quais, somam-se duzentas e trinta (230) peças, enquanto no Mirador de Parelhas foram identificados apenas duas (02) peças de adornos corporais em ossos. As alterações tafonômicas e os processos deposicionais decorrentes de contextos múltiplos que incluem o estado de conservação do sítio Pedra do Alexandre, além das perturbações antrópicas recentes que ocorreram no Sítio Mirador de Parelhas, influenciam diretamente no estado de conservação dos objetos de adornos identificados no registro arqueológico. No gráfico 1 observa-se a distribuição das matérias-primas utilizadas na confecção dos adornos corporais.

\footnotetext{
${ }^{4}$ Esse número corresponde ao quantitativo de contas e pingentes. Como todos os adornos evidenciados na escavação não apresentavam amarrações, se optou pela contagem individual.
} 


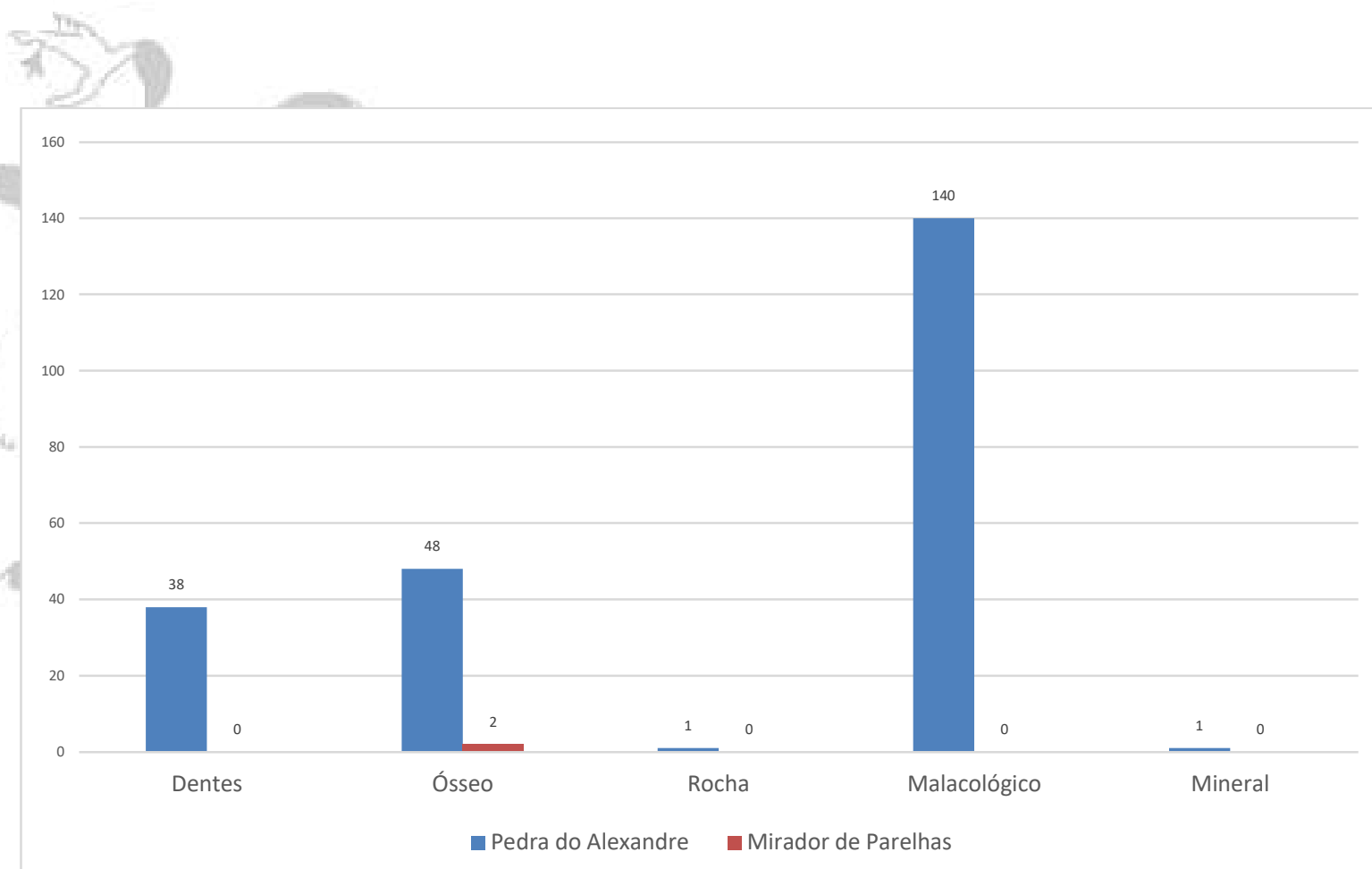

Gráfico 1: Distribuição das matérias-primas utilizadas na confecção dos adornos nos sítios Pedra do Alexandre e Mirador de Parelhas.

No sítio Pedra do Alexandre observa-se 140 adornos confeccionados a partir de conchas e moluscos, dos quais 136 são contas de valvas de moluscos (Olivella Nivea) e estavam associados a uma criança (Figura 4). 


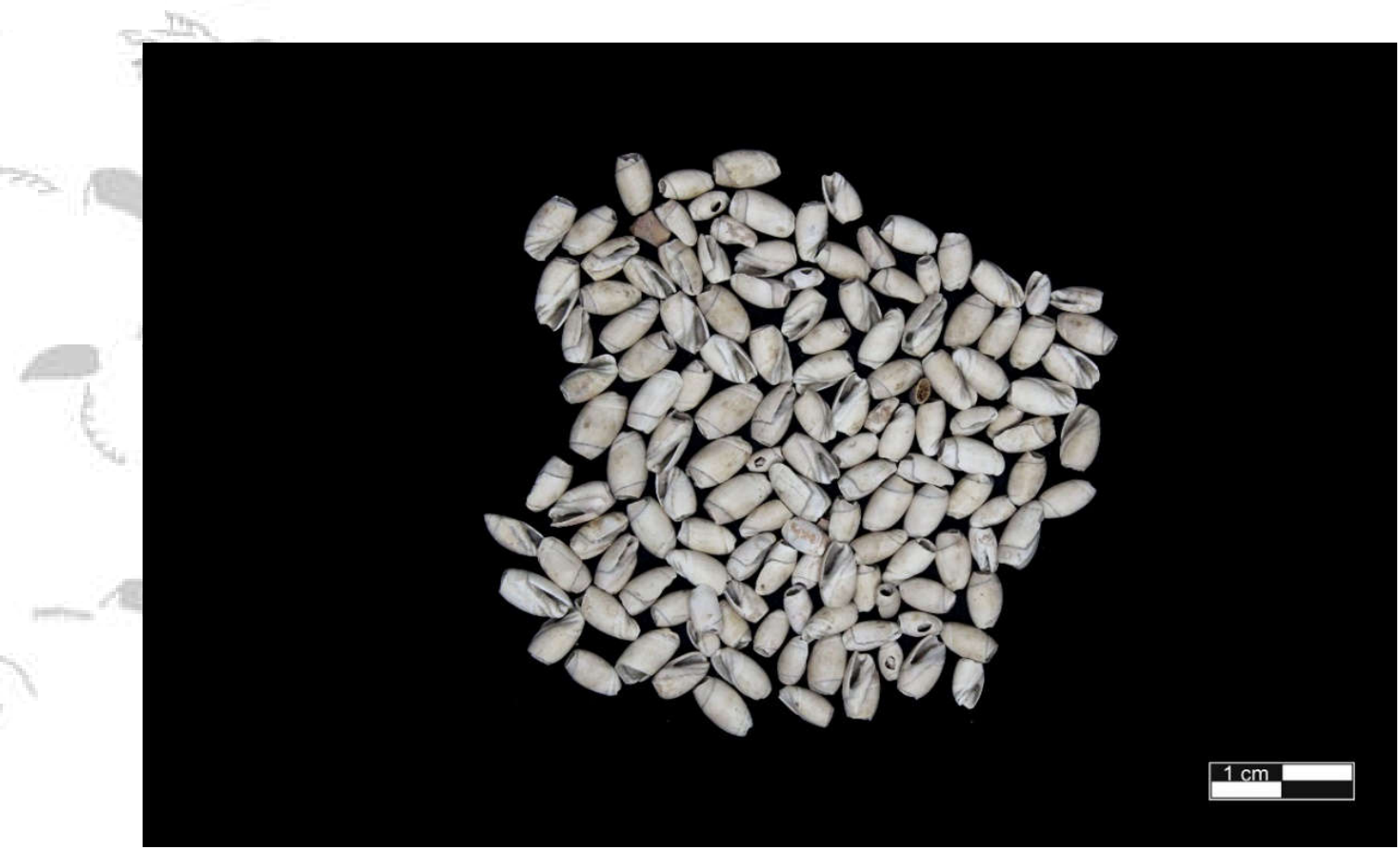

Figura 4: Contas de valvas de moluscos (Olivella Nivea), associadas ao indivíduo 6, criança. Sítio Pedra do Alexandre. Foto: Camila Ferreira, ano 2019.

Nos sítios da Região Nordeste do Brasil, também são identificados adornos de material malacológico. No Sítio Toca do Enoque, por exemplo, foram verificados pingentes realizados a partir de conchas e associações de caramujos Aruá (Megalobulimus) no mobiliário fúnebre como acompanhamento funerário em quase todos os enterramentos (Luz, 2014).

Além dos adornos de conchas e moluscos, também foram encontrados pingentes de ossos de cervídeos (Mazama gouazoubira e/ou americana). Para a confecção dos 
adornos o osso (metapodial posterior) foi cortado longitudinalmente em seu plano sagital, onde cada metade foi utilizada como um pingente (Queiroz et al, 2018) (Figura 5).

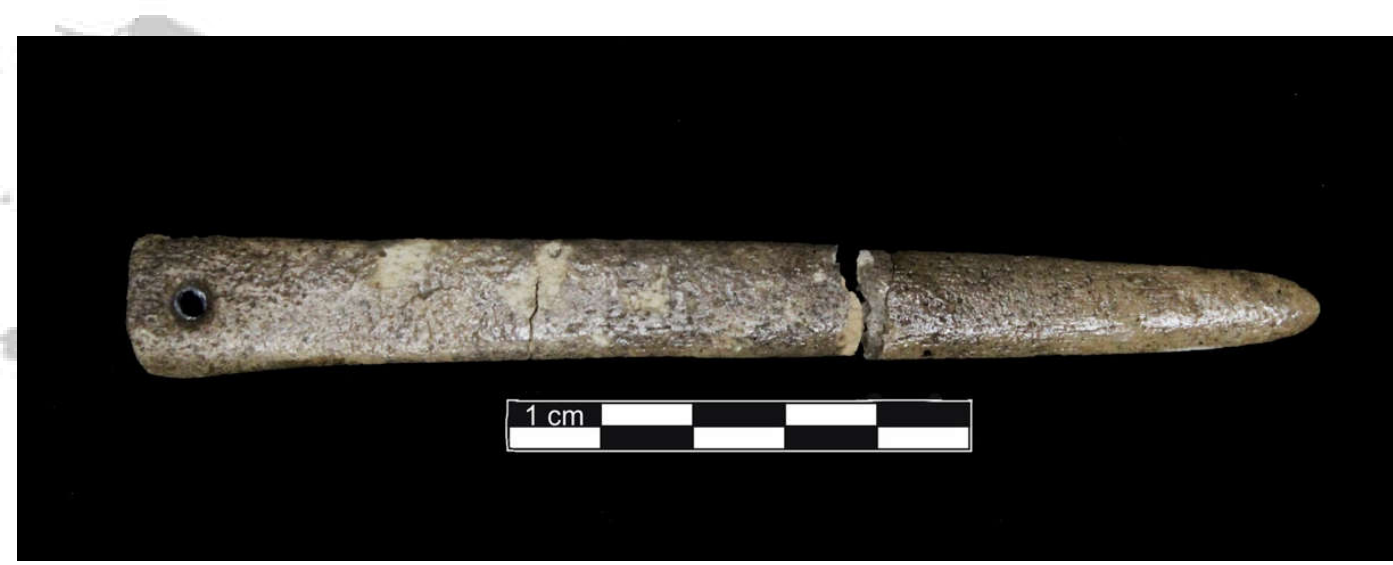

Figura 5: Pingente de osso de cervídeo com quebras, fraturas e fissuras transversais, identificado no Sítio Pedra do Alexandre. Foto: Camila Ferreira, ano 2019.

Observa-se esse tipo de adorno em outros sítios pré-históricos no Nordeste, tais como Justino (SE), Toca do Enoque (PI), Furna do Estrago (PE), Mirador de Parelhas (RN) e podendo ser inferido um possível contato ou proximidade sociocultural dessas populações, visto que além do uso da mesma espécie de cervídeo, também é observada técnica de preparação de superfície similar. Sobre o conjunto dos processos técnicos, observa-se que os adornos, cujas matérias-primas são dentes e sementes, geralmente são utilizados em seu formato original, não sofrendo ação de corte ou facetamento, apenas de polimento, o que promove o brilho à peça. Já o material ósseo costuma ter uma maior preparação da superfície 
com o corte, geralmente nas extremidades em que se localizam as perfurações e o polimento da superfície. A técnica do polimento também é comum em adornos confeccionados em minerais e rochas, visto que estes apresentam maior dureza na superfície, (Figura 6).

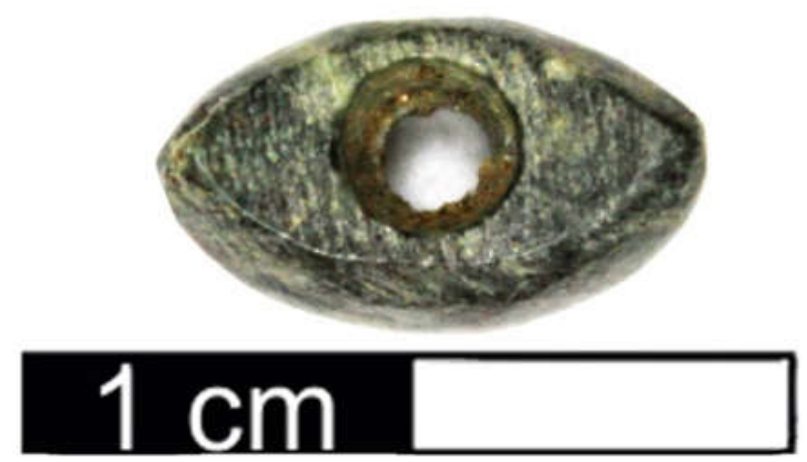

Figura 6: Conta de mineral com identificação da técnica de facetamento, Sítio Pedra do Alexandre. Foto: Camila Ferreira, ano 2019.

Nos sítios Pedra do Alexandre e Mirador de Parelhas os pingentes estavam associados à uma criança e apresentaram perfurações intencionais bicônicas (Figura 6). Todavia, a associação desses pingentes a categoria dos infantes necessita de mais dados para ser confirmada. 


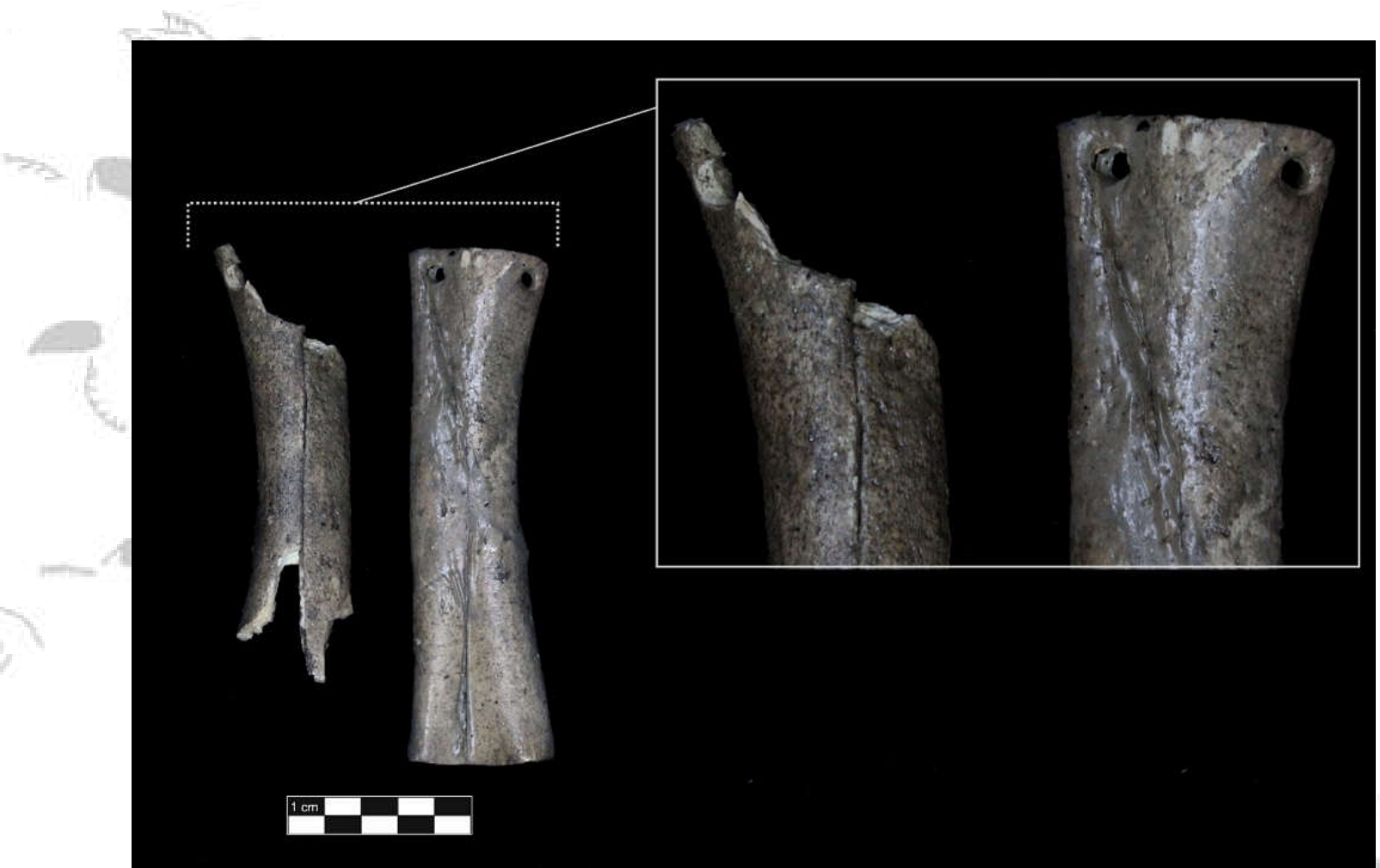

Figura 7: Pingentes de osso de cervídeo, associados ao enterramento infantil no Sítio Mirador de Parelhas. Foto: Camila Ferreira, ano 2019. 


\section{OS ADORNOS NOS REGISTROS RUPESTRES DO SERIDÓ}

Dentro do panorama inicial dos estudos sobre o conjunto pictórico rupestre da Área Arqueológica do Seridó, Martin (1998) identificou que as pinturas compartilhavam traços gráficos característicos da Tradição ${ }^{5}$ Nordeste (Guidon, 1981; Pessis, 1993) tais como: presença majoritária de grafismos naturalistas, com ampla variedade temática (figuras antropomorfas, fitomorfas e zoomorfas); figurações de pequeno tamanho (entre 5 e $10 \mathrm{~cm}$ ); posturas dinâmicas; utilização de técnicas de traços leves e seguros; e representações de cenas reconhecíveis (dança, guerra, sexo) habilmente representadas (Martin, 1998; Pessis, 1987; Pessis, et al 2005).

A partir de estudos que visaram identificar similaridades e diferenças dentro do conjunto rupestre da Tradição Nordeste na região, foi possível identificar particularidades gráficas que resultaram na Subtradição ${ }^{6}$ Seridó. Essa subtradição é caracterizada por uma dominância de antropomorfos com cabeças côncavas (castanha de caju); presença de atributos culturais (objetos e adornos); elementos secundários que permitem a identificação de certas espécies de animais e figuras emblemáticas entre elas (cenas herméticas e pirogas) (Figuras 8 e 9).

\footnotetext{
${ }^{5} \mathrm{O}$ conceito de Tradição é atribuído às classes ordenadas, agrupadas a partir da seleção de elementos ou técnicas similares com certa persistência temporal, que caracterizam um conjunto de vestígios arqueológicos. Essas classes podem ser associadas através de seus atributos e contextos à distintos grupos culturais.

${ }^{6} \mathrm{O}$ conceito de subtradição está fundamentado na constatação de que existem figuras com diferentes formas, em espaços geográficos diferentes. Esses grafismos apresentariam novos elementos técnicos e temáticos incorporados, a partir de novos ambientes e novas experiências.
} 
Em continuidade às pesquisas sobre caracterização gráfica na região, Martin (2003), estabeleceu três estilos ${ }^{7}$ gráficos (Serra da Capivara II, Carnaúba e Serro Corá). O estilo Serra da Capivara II foi definido como o primeiro momento gráfico das representações pictóricas em alguns sítios da região, considerando as semelhanças com as pinturas encontradas no Parque Nacional Serra da Capivara; o estilo Carnaúba representa a segunda fase da atividade pictórica na região, contendo características gráficas como representações de cabeça em formato côncavo nas figuras antropomorfas, dinamismo e atributos culturais (adornos e objetos); e o estilo Serro Corá, terceiro momento gráfico na região, se distingue dos demais por conter traços mais geometrizados, assemelhando-se à tradição Agreste.

\footnotetext{
${ }^{7}$ Os estilos gráficos compõem uma unidade mais particularizada de análise. A noção de estilo trabalhada por Pessis (1989) para as pinturas rupestres do Parque Nacional Serra da Capivara corresponde a unidades compostas por uma estrutura de apresentação e técnicas gráficas destacadas no interior das categorias de entrada estabelecidas para o estudo dos registros rupestres. Os estilos seriam, portanto, categorias que, associadas a uma cronologia permitiriam precisar identidades gráficas (Cisneiros, 2008).
} 


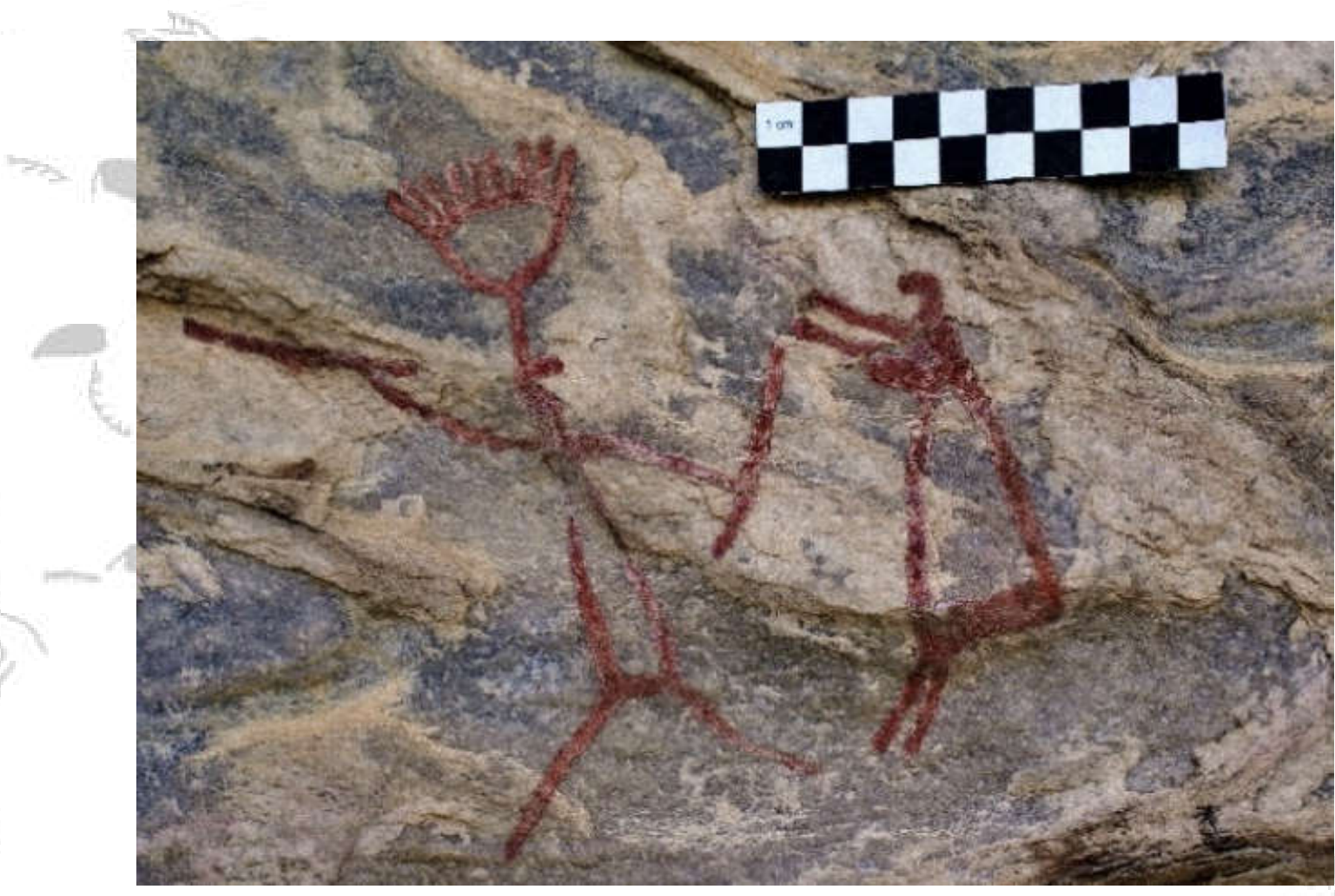

Figura 8: Cena característica da Tradição Nordeste, subtradição Seridó. Antropomorfos com cabeças côncavas, adornos e objetos. Sítio arqueológico Xique-Xique I, Carnaúba dos Dantas. Município de Carnaúba dos Dantas - RN. Foto: Nathalia Nogueira, ano 2016.

A variedade temática, a diversidade e a composição dos elementos secundários do estilo gráfico Carnaúba, que constituem as representações pictóricas dominantes na região do Seridó Potiguar, permitiu um estudo tipológico dos adornos de cabeça dos antropomorfos em composição de cenas. 


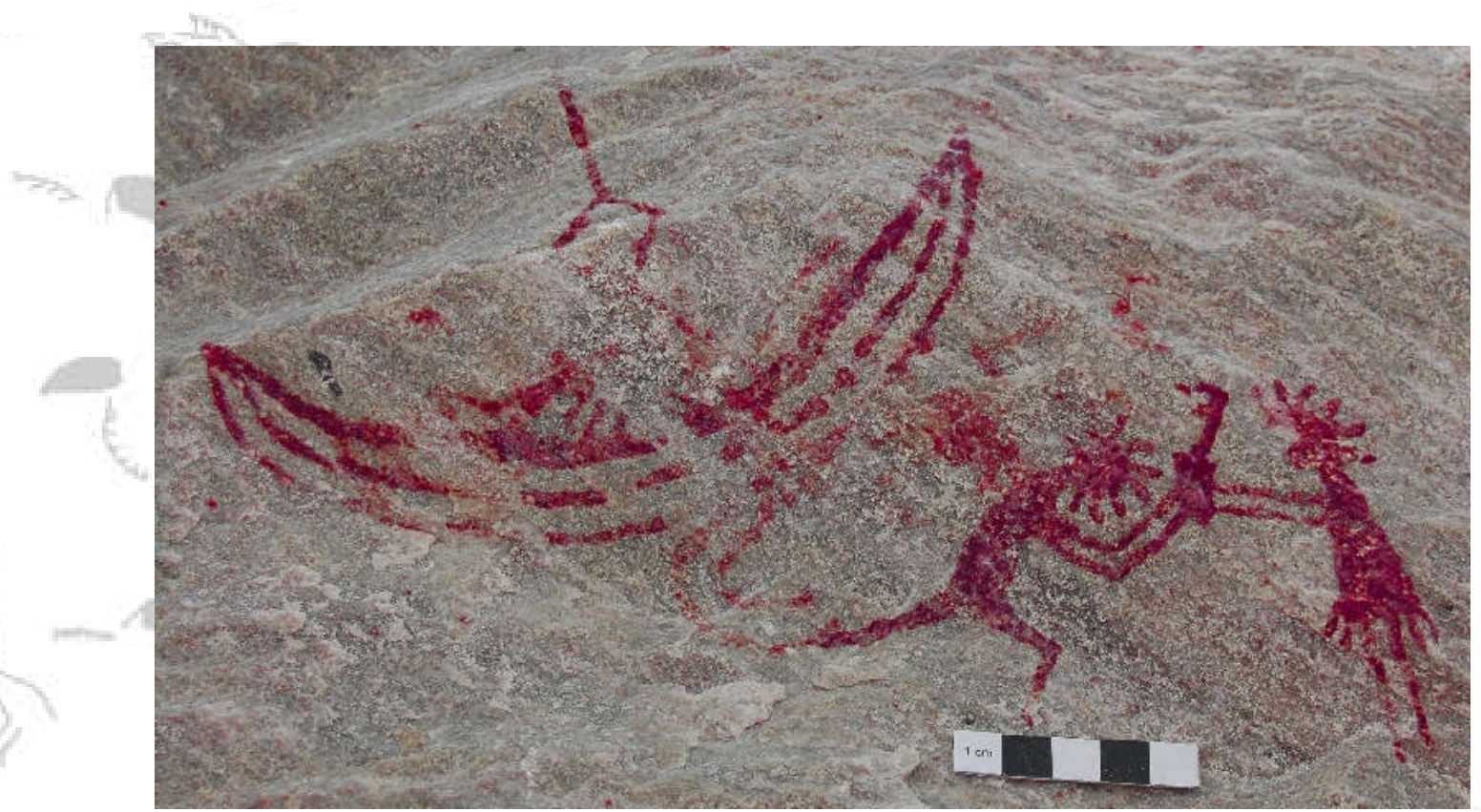

Figura 9: Cena hermética característica da Tradição Nordeste, subtradição Seridó, estilo Carnaúba. Antropomorfos com cabeças côncavas, adornos e presença de espécie de piroga. Sítio arqueológico Casa Santa, Carnaúba dos Dantas. Município de Carnaúba dos Dantas - RN. Foto: Nathalia Nogueira, ano 2016.

A partir da análise dos dados foram estabelecidos dez (10) tipos diferentes de adornos, formando conjuntos que se agregam por suas similaridades. Essas similaridades foram estabelecidas mediante variações tanto morfológica quanto do posicionamento do adorno, em relação à cabeça do indivíduo (Quadro 3). 


\begin{tabular}{|l|l|l|}
\hline \multicolumn{1}{|c|}{ Tipos } & \multicolumn{3}{|c|}{ Variantes } \\
\hline Tipo 1 & & \\
\hline Tipo 2 & & \\
\hline Tipo 3 & & \\
\hline Tipo 4 & & \\
\hline Tipo 5 & & \\
\hline Tipo 6 & \\
\hline Tipo 7 & \\
\hline Tipo 8 & \\
\hline Tipo 10 & \\
\hline
\end{tabular}

Quadro 3: Tipologias dos adornos de cabeça presentes nas unidades cenográficas segregadas 
Os dez (10) tipos de adornos se distribuem em vinte e nove (29) cenas com as seguintes temáticas: sexo, violência, caça e herméticas. As cenas classificadas como herméticas são as mais abrangentes nos sítios arqueológicos estudados, elas detêm a maior quantidade de tipos de adornos cabeça. Apesar da dificuldade no reconhecimento cognitivo dessas cenas, por apresentarem códigos mais velados, a diferença entre seus elementos gráficos e o agenciamento dos elementos cenográficos permitiu a criação de cinco (05) subcategorias: apresentação frontal, apresentação lateral, família, atividade grupal, atividade em dupla (Quadro 4). 


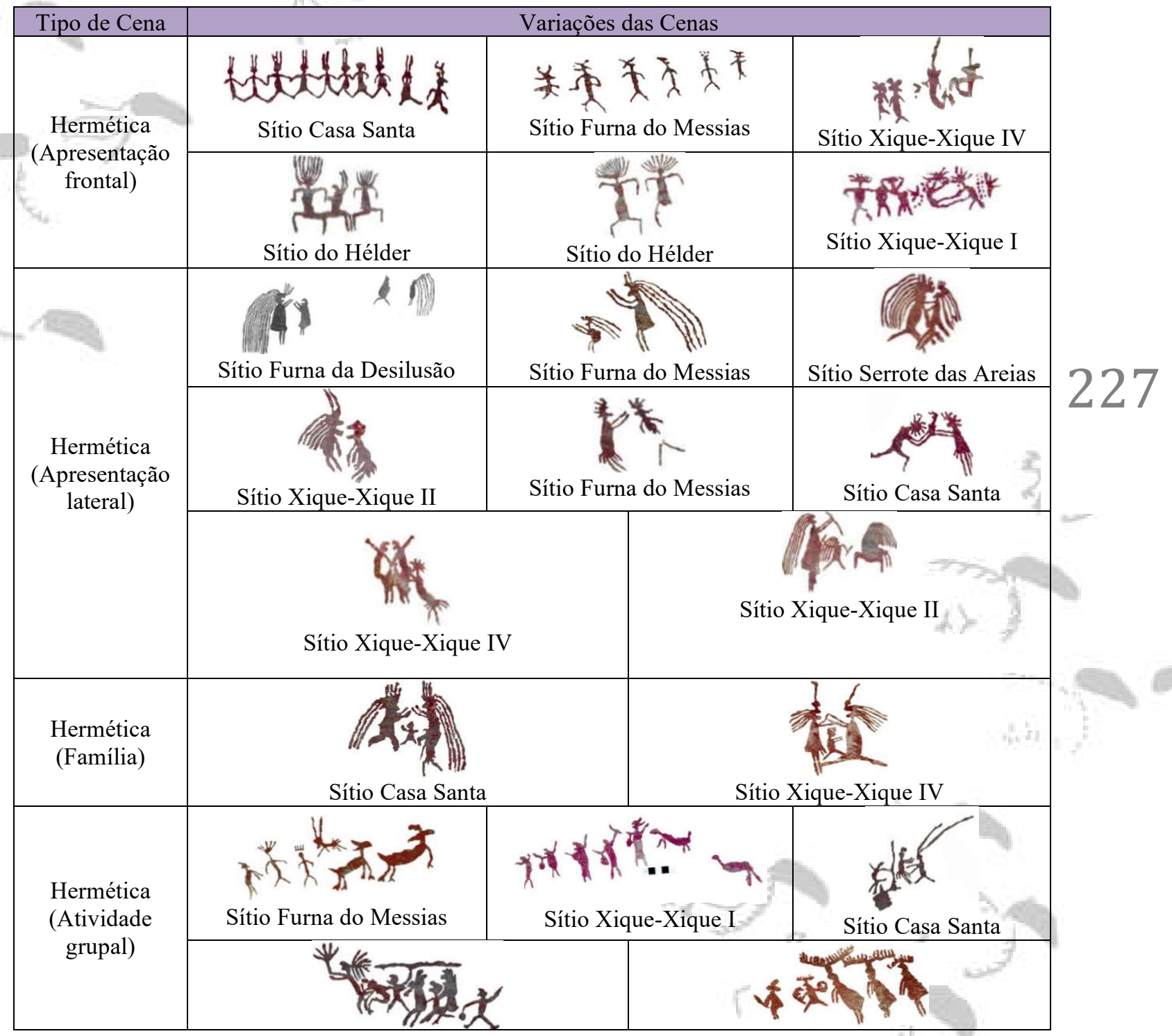




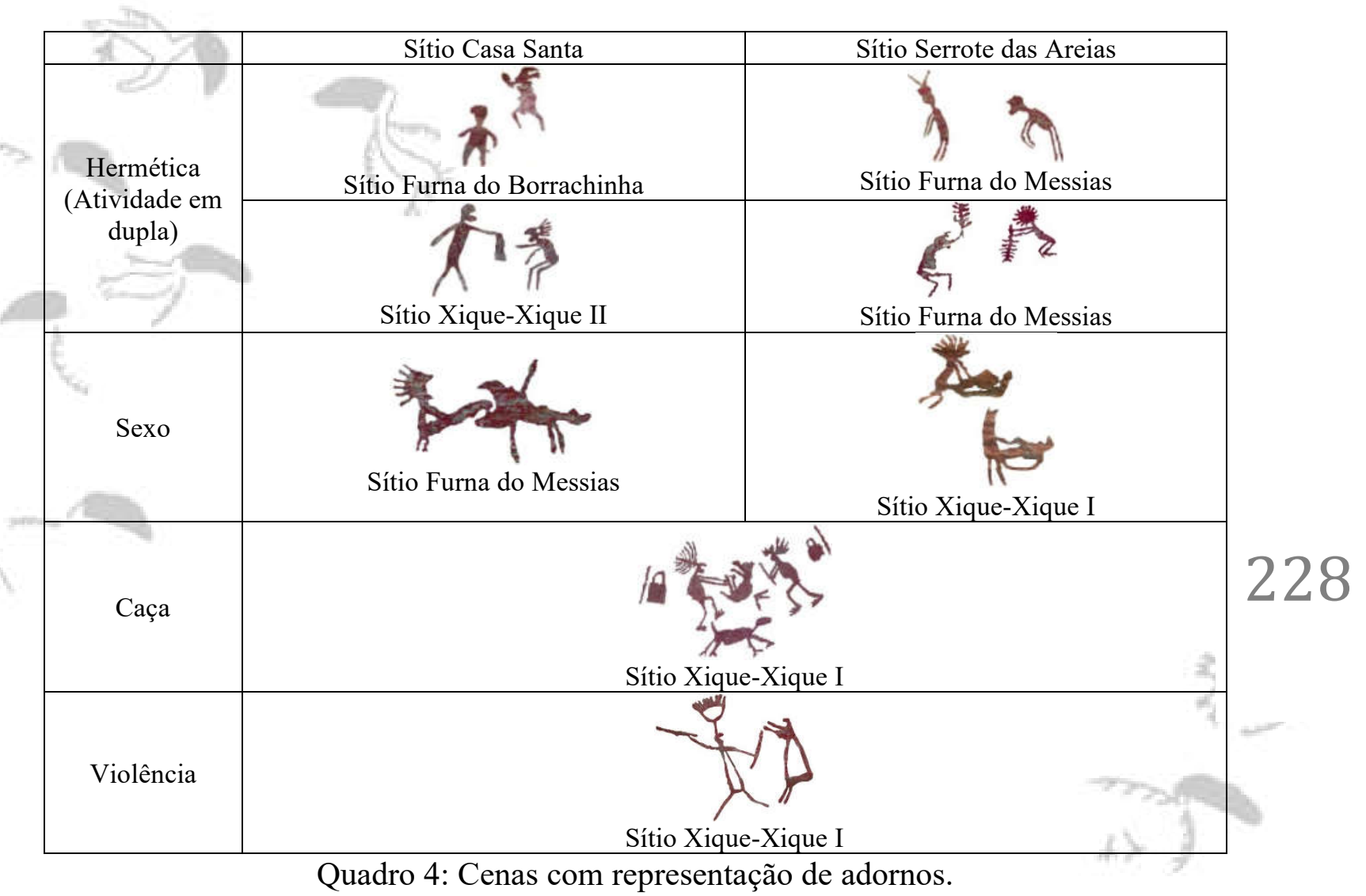


A partir do Quadro 4, pode-se observar as seguintes representações de adornos:

- nas cenas de sexo, apenas um dos antropomorfos é representado com adorno, este em todas as cenas apresenta-se com falo;

- na cena de violência, apenas um dos antropomorfos apresenta adorno, este detém na mão objetos cujo posicionamento cenográfico parece representar dominação;

- na cena de caça, ambos antropomorfos são representados com o mesmo tipo de adorno;

- nas cenas herméticas, classificadas como de apresentação (frontal e lateral) e família, todos os antropomorfos estão representados com o mesmo tipo gráfico de adorno, com exceção das cenas de apresentação lateral dos sítios Xique-Xique II e Xique-Xique IV;

- nas cenas classificadas como atividades grupais, apenas alguns antropomorfos são representados com adornos, nessas apresentam-se graficamente distinções entre os adornos;

- nas cenas herméticas classificadas como atividades em dupla, apenas um dos antropomorfos é representado com adorno.

As distinções de adornos nos antropomorfos que compõe as cenas, podem ser indicativos de diferenças sociais, sexuais e etárias, visto que os adornos são considerados como elementos de distinção social dentro do mesmo grupo. Os registros rupestres estudados evidenciam comportamentos culturais dos grupos pretéritos, destacando preferências sobre a utilização do adorno de cabeça, em relação aos momentos cenográficos (tipos de cenas) (Cisneiros \& Nogueira, 2016). A partir de um conjunto comparativo entre as similaridades e diferenças expostas 
nas cenas, foi possível identificar em que circunstâncias os grupos culturais empregavam determinados tipos de adornos de cabeça (Gráfico 2).

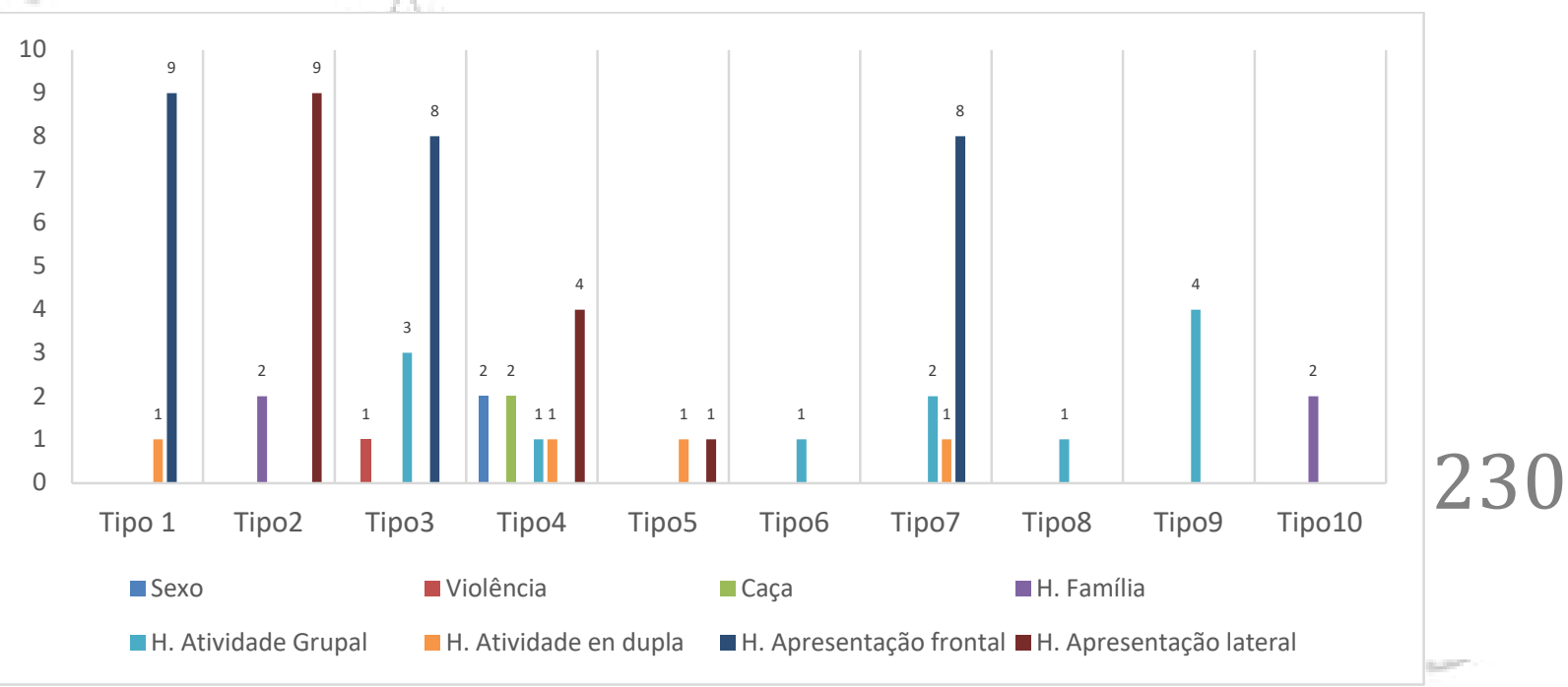

Gráfico 2: Distribuição dos tipos de adornos nas cenas rupestres.

Conforme o gráfico acima, pode ser observado que os adornos do tipo 4 aparecem representados em uma maior quantidade de cenas, entre elas sexo, caça e cenas herméticas classificadas como atividade grupal, atividade em dupla e apresentação lateral; enquanto as cenas de maior diversidade de adornos são as cenas herméticas, classificadas como atividade grupal, nessas cenas há uma diversificação tipológica de adornos integrados uma única unidade cenográfica. 


\section{CONSIDERAÇÕES FINAIS}

O adorno, no universo simbólico pré-histórico pode ser evidenciado através da cultura material, resgatada em intervenções arqueológicas ou por meio das representações gráficas exteriorizadas nos suportes rochosos; ambas são resultados de comportamentos culturais que indicam uma funcionalidade.

O estado de conservação dos adornos referentes a períodos pré-históricos, muitas vezes, tende a limitar os dados de algumas pesquisas. Isso porque em sua maioria a confecção dos adornos é realizada a partir de elementos orgânicos, cuja longevidade é bastante restrita. Isso significa que os adornos verificados em registros arqueológicos nem sempre correspondem apenas aos objetos utilizados pelo grupo.

As pinturas rupestres da Área Arqueológica do Seridó apresentam em sua totalidade adornos localizados na cabeça das representações antropomórficas e, diferentemente de outros estilos gráficos, não se percebe variações na localização desses adornos, tais como braços e pernas.

Nas referências etnográficas brasileiras sobre tipologias de adornos de cabeça, em sua grande maioria são confeccionados com materiais orgânicos mais leves, sobretudo, penas, couros, cordéis e palhas. Esses elementos são de difícil conservação no registro arqueológico, sobretudo em datações recuadas como é o caso dos enterramentos dos sítios Mirador de Parelhas e Pedra do Alexandre. 
Nesses sítios foram evidenciados materiais orgânicos de resistência maior, como ossos (em processo de mineralização), dentes, conchas, rochas e minerais.

Assim, não foi possível verificar correlações diretas entre os adornos presentes nas pinturas rupestres e nos enterramentos. Porém é possível inferir que, os grupos que habitaram a Área Arqueológica do Seridó em períodos pré-históricos, utilizavamse de diversos tipos de adornos, entre elas, adornos de cabeça, colares e pingentes; confeccionados com diferentes matérias-primas; e utilizados em contextos funerários, acompanhando os indivíduos sepultados; e nos cenários rupestres, retratados em cenas cotidianas desses grupos, como rituais, caça, sexo e violência.

\section{REFERÊNCIAS BIBLIOGRÁFICAS}

BORGES, F. M. Os sítios arqueológicos Furna do Umbuzeiro e Baixa do Umbuzeiro: caracterização de um padrão de assentamento na Área Arqueológica do Seridó - Carnaúba dos Dantas - RN, Brasil. 2010. 322 f. Tese, Doutorado em Arqueologia, Programa de PósGraduação em Arqueologia, Universidade Federal de Pernambuco, Recife, 2010.

BUTTO, Ana.; FIORE, Danaé. Adornos corporales y género en las fotografías etnográficas de Yámana/Yagán. Universitas, Cuenca, ano 15, n. 27, p. 67-92, 2017.

DANTAS, José de Azevedo. Indícios de uma civilização antiquíssima. João Pessoa: Fundação Casa de José Américo e Instituto Histórico e Geográfico Paraibano, 1994. 200 p. (Apresentação e texto de Gabriela Martin. Manuscrito datado de 1926 na Biblioteca do Instituto Histórico e Geográfico Paraibano e que apresenta 156 lâminas com desenhos de pinturas e gravuras rupestres do Rio Grande do Norte e da Paraíba). 
CASTRO, Viviane. Marcadores de Identidades Coletivas no contexto funerário préhistórico no Nordeste do Brasil. 2009. Tese (Doutorado em Arqueologia) - Universidade Federal de Pernambuco, Recife, 2009. 310f.

CISNEIROS, Daniela. Similaridades e Diferenças nas Pinturas Rupestres Pré-Históricas de Contorno Aberto no Parque Nacional Serra da Capivara - PI. Tese (Doutorado) Programa de Pós-graduação em Arqueologia, Centro de Filosofia e Ciências Humanas, Universidade Federal de Pernambuco. Recife, 2008.

CISNEIROS, Daniela. \& NOGUEIRA, Nathalia. Representações rupestres de adornos de cabeça nos antropomorfos na área arqueológica do Seridó-RN. Revista Clio Arqueológica. Universidade Federal de Pernambuco-UFPE, Recife, 2016.

CISNEIROS, Daniela. Práticas funerárias na Pré-História do Nordeste do Brasil. 2003. Dissertação (Mestrado em História) - Universidade Federal de Pernambuco, Recife, 2003. $161 \mathrm{f}$.

CISNEIROS, Daniela.; NOGUEIRA, Nathalia.; \& TAVARES, Bruno. Cronología y dinámica espacial en sitios de refugio y al aire libre en la zona arqueológica de Seridó, Rio Grande do Norte (Brasil), 2020.

DORTA, Sônia. A plumária indígena brasileira: no museu de arqueologia e etnologia da USP. 2. ed. São Paulo: Editora da Universidade de São Paulo: MAE/Impressa oficial de São Paulo, 2000.

EHRENREICH, Paul. Índios Botocudos do Espírito Santo no Século XIX. Espírito Santo: GSA Gráfica e Editora, 2014.

FERNÁNDEZ, Esteban. Los objetos de adorno - colgantes del Paleolítico superior e del Mesolítico em la Cornisa Cantábrica y en el Valle del Ebro: una visión europea. Salamanca: Ediciones Universidad de Salamanca, 2006.

GUIDON, Niède. Tradições e estilos da Arte Rupestre no Sudeste do Piauí. Pré-história Brasileira Aspectos da Arte Parietal. Catálogo de Exposição. São Paulo, USP, p.19-20. 1981. 


\section{Clio Arqueológica 2020, V35N3, p199-235, CISNEIROS; NOGUEIRA, SANTOS

LEROI-GOURHAN, Andrè. O gesto e a palavra 2 - memória e ritmos. Lisboa: Edições $70,1965$.

LUZ, Maria de Fátima da. Práticas funerárias na Área Arqueológica da Serra da Capivara, Sudeste do Piauí, Brasil. 2014. Tese (Doutorado em Arqueologia) - Universidade Federal de Pernambuco, Recife, 2014.

MARTIN, Gabriela. Fronteiras Estilísticas e Culturáis na Arte Rupestre da Área Arqueológica do Seridó-RN. Revista Clio - Arqueológica. Universidade Federal de Pernambuco-UFPE, Recife, 2003.

MARTIN, Gabriela. Pré-História do Nordeste do Brasil. 5. ed. Recife: Editora Universitária da UFPE, 2008.

MAYER, Bar-yosef. Towards a typology of stone beads in the Neolithic Levant. Journal of Field Archaeology, Massachusetts, n. 2, p. 129-142, 2013.

MAYOR, Begoña; BENITO, Josep. Mujeres, hombres y objetos de adorno. In: ROSADO, Helena Bonet. (Org). Las Mujeres en la prehistoria. Valéncia: Museu de Prehistoria de Valéncia, 2006, p. 63-78.

NOGUEIRA, M. Ocupações pré-históricas a céu aberto no vale do Rio da Cobra Carnaúba dos Dantas e Parelhas - RN. 2017. Tese, Doutorado em Arqueologia, Programa de Pós-Graduação em Arqueologia, Universidade Federal de Pernambuco, Recife, 2017.

OBERMAIER, Hugo. El Hombre Fósil. Comisión de investigaciones paleontológicas y prehistóricas, Memoria, n. 9. Madrid, 1925.

PALLET, Patrick. Les Arts Préhistoriques. Lyon: Éditions Ouest-France. 2006.

PESSIS, Anne-Marie; COSTA, Adriene; Cisneiros, Daniela; CASTRO, Viviane. Prospecção arqueológica de sítios com registros rupestres na Chapada do Araripe. Recife: Clio Arqueológica, p. 123-140. 2005.

PESSIS, Anne-Marie. Art rupestre préhistorique: Premiers registres de la mise en scene. Tese (Doutorado de Estado) - Université de Paris X - Nanterre. 1987. 
PESSIS, Anne-Marie. Registros rupestres, perfil gráfico e grupo social. Revista Clio Arqueológica. Universidade Federal de Pernambuco-UFPE, Recife, 1993.

QUEIROZ, Albérico. et al. Os adornos em osso de mazama na sepultura 118, Cemitério b: Sítio Arqueológico Justino, Canindé do São Francisco, Sergipe, Brasil. Clio Arqueológica, Recife, v. 33, n. 1, p. 10-25, 2018.

SANTOS, Camila Ferreira dos. Adornos Pré-históricos no Nordeste do Brasil: Técnicas, Usos e Funções. Dissertação (Mestrado em Arqueologia) - Universidade Federal de Pernambuco, Recife, 2020.

SEEGER, Anthony; MATTA, Roberto da; CASTRO, Eduardo Viveiro de. A construção da pessoa nas sociedades indígenas brasileiras. Núcleo de Estudos e Assuntos Indígenas. Universidade Federal do Tocantins Campus de Porto, 1979.

VELTHEM, Lúcia. Trançados indígenas norte amazônicos: fazer, adornar, usar. Revista de Estudos e Pesquisas. Fundação Nacional do Índio, Brasília, 2007.

VIALOU, Agueda; VIALOU, Denis. Manifestações simbólicas em Santa Elina, Mato Grosso, Brasil: representações rupestres, objetos e adornos desde o Pleistoceno ao Holoceno recente. Boletim do Museu Paraense Emílio Goeldi, Belém, v. 14, n. 2, p. 343$365,2019$. 